\title{
Rock procurement and use during the Middle Neolithic: The macrolithic tools of Dambach-la-Ville (Alsace, France)
}

\author{
Florent Jodry ${ }^{1}$, Marion Delloul ${ }^{2}$, Christophe Croutsch ${ }^{2}$, Philippe Duringer ${ }^{3}$, \\ Gilles Fronteau ${ }^{4}$
}

1. Institut National de Recherches Archéologiques Préventives, 10 rue d’Altkirch-67100 Strasbourg, France.

Email: florent.jodry@inrap.fr

2. Archéologie Alsace, 11 rue Champollion, 67600Selestat, France.

Email: Delloul: marion.delloul@archeologie.alsace; Croutsch: christophe.croutsch@archeologie.alsace

3. Institut de Physique du Globe/Ecole et Observatoire des Sciences de la Terre, 1 rue Blessig, 67084 Strasbourg.

Cedex, France. Email: duringer@unistra.fr

4. Université de Reims Champagne-Ardenne, GEGENAA EA 3795, 51097 Reims, France.

Email: gilles.fronteau@univ-reims.fr

\begin{abstract}
:
A preventive archaeological excavation carried out in 2012 at Dambach-la-Ville (Bas-Rhin, France) uncovered a large Middle Neolithic settlement (Upper Rhine West Bischheim group) dating from the second half of the 5th millennium BCE. The site comprised a very large assemblage of welldated macrolithic tools (more than 600). Grinding stones, including about roughouts, make up the bulk of the assemblage. Morphological analyses indicate that certain types of use-wear are linked directly to specific types of rock. The variety of rock types is unusual for this period. In fact, contrary to other assemblages from the same period mainly made up of Lower Triassic sandstone (Vosges sandstone; 43\%), the tools fashioned on this settlement are mostly made from sedimentary rocks of the Permian and Lower Triassic (possible sources at $15 \mathrm{~km}$ ), and more rarely from plutonic and metamorphic rocks (possible sources between 5 and $15 \mathrm{~km}$ ). The use of rough textured rocks such as arkosic sandstone or microconglomerate largely dominating the assemblage. This one also includes a large group of hammerstones from different rock types (sedimentary, plutonic, volcanic and metamorphic). More than half are silicified micritic limestones, a rock that is extremely rare and can be unambiguously traced to a single outcrop about 15 kilometres from the site. This systematic interdisciplinary study of the tools and their petrography offers the opportunity to explore questions regarding provenance and procurement networks in Alsace around 4150 BCE.
\end{abstract}

Keywords: grinding tools; querns; hammerstones; Neolithic; procurement; quarry

\section{Introduction}

A preventive archaeological excavation carried out near the town of Dambach-la-Ville (Alsace, France), 40 kilometres south of Strasbourg, led in 2011 to the discovery of a large Middle Neolithic settlement (Figure 1) dating from about 4150 BCE (Croutsch et al. 2016).

Published by the School of History, Classics and Archaeology, University of Edinburgh ISSN: 2055-0472. URL: http://journals.ed.ac.uk/lithicstudies/ 
The settlement is located at the foot of the Vosges granite Bernstein Massif and covers a surface of over three hectares in the lowlands of Bruch de l'Andlau, one of Alsace's largest wetlands.

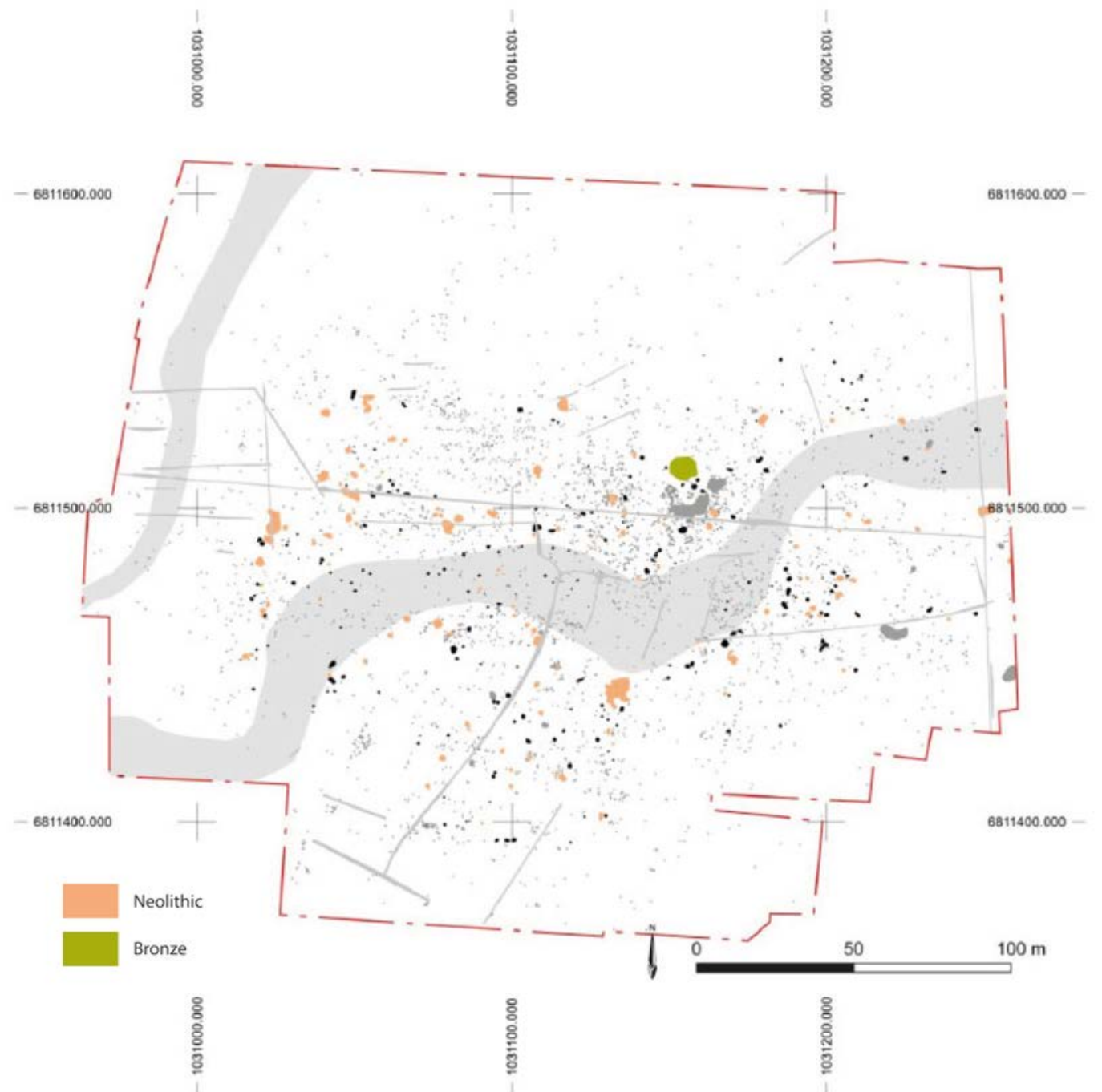

Figure 1. Map of the archaeological features of the Neolithic settlement of Dambach-la-Ville (Ch. Croutsch).

The Neolithic occupation comprises just over 450 structures (pits, post holes, wells). One of the more remarkable finds is the wood lining of a well (preserved under the water table). Dendrochronological analyses, supported by pottery studies, suggest that the settlement spanned about 50 years, from circa 4172 to 4118 BCE. Archaeological artefacts are particularly abundant. The grinding and polishing tool assemblage alone includes more 4,000 artefacts.

\section{The grinding tools}

The analysis of this exceptional assemblage has led to the identification of the different phases of the operational sequence of grinding tool manufacture and to aspects of tool function. This assemblage is currently by far the richest for the Middle Neolithic in Alsace and the source of many questions. The current article focuses on rock procurement and tool technology as the choice of material serving to fashion the macrolithic tools forced the tool maker to adhere to a specific sequence of manufacture. 


\subsection{Modes of rock procurement and the operational sequence of quern production}

The tools can be divided into three rock families (Table 1): sedimentary (4,321 examples; 2.2 tonnes), plutonic (20 items; $21 \mathrm{~kg}$ ) and metamorphic (1 item; $4.8 \mathrm{~kg}$ ). The sedimentary family, by far the largest, can be further broken down into coarse sandstones, arkosic sandstones, microconglomerates and fine sandstones (Voltzia). The whole of the assemblage was subject to visual petrographic analyses by $\mathrm{Ph}$. Duringer to identify the procurement zones. This was followed by microscopic petrographic analyses by G. Fronteau intended to approach the question of their mechanical qualities.

Table 1. Quantitative data of rock procurement at Dambach-la-Ville.

\begin{tabular}{lllll}
\hline Petrography & No. & $\%$ & Weight $(\mathbf{k g})$ & $\%$ \\
\hline Vosges sandstone & 982 & 22.6 & 839 & 36.4 \\
\hline Voltzia sandstone & 103 & 2.4 & 31 & 1.3 \\
\hline Undetermined sandstone & 1,978 & 45.6 & 393 & 17.1 \\
\hline Total Triassic & $\mathbf{3 , 0 6 3}$ & $\mathbf{7 0 . 6}$ & $\mathbf{1 , 2 6 3}$ & $\mathbf{5 4 . 8}$ \\
\hline Arkosic sandstone & $\mathbf{7 9 6}$ & 18.3 & 543 & 23.6 \\
\hline (Micro)conglomerate & 462 & 10.6 & 473 & 20.5 \\
\hline Total Permian & $\mathbf{1 , 2 5 8}$ & $\mathbf{2 8 . 9}$ & $\mathbf{1 , 0 1 6}$ & $\mathbf{4 4 . 1}$ \\
\hline Total sedimentary rocks & $\mathbf{4 , 3 2 1}$ & $\mathbf{9 9 . 5}$ & $\mathbf{2 , 2 7 9}$ & $\mathbf{9 8 . 9}$ \\
\hline Granite & 20 & 0.5 & 21 & 0.9 \\
\hline Total plutonic rocks & $\mathbf{2 0}$ & $\mathbf{0 . 5}$ & $\mathbf{2 1}$ & $\mathbf{0 . 9}$ \\
\hline Gneiss & 1 & 0 & 5 & 0.2 \\
\hline Total metamorphic rocks & $\mathbf{1}$ & $\mathbf{0}$ & $\mathbf{5}$ & $\mathbf{0 . 2}$ \\
\hline TOTAL & $\mathbf{4 , 3 4 2}$ & $\mathbf{1 0 0}$ & $\mathbf{2 , 3 0 5}$ & $\mathbf{1 0 0}$ \\
\hline
\end{tabular}

Macrolithic tools offer a relatively clear indication of the rock types and means of lithic procurement. The rocks were procured either by extraction or simple surface collection near the site in three different formats (angular slabs, pebbles and irregular blocks). The Val de Villé source is located at the intersection of the crystalline and sedimentary (Permian and Triassic) massifs offering a relatively wide lithological variety of rock types to the residents of Dambach-la-Ville. The main rocks exploited in the Neolithic period, granites and coarse Triassic sandstones (Jodry 2012), are rivalled, in this case, by Permian arkosic sandstone, an unexpected rock regarding its rarity within Alsatians corpus.

The analysis of the morphology of the blanks discovered at the site indicates that the initial format was closer to that of a "block", a format that greatly exceeds that of angular slabs (Figure 2) and pebbles. It therefore appears that there is a considerable investment put into fashioning grinding tools into shape at the site itself as evidenced by a great amount of rough unworked blocks (33; $86 \mathrm{~kg}$ ) (Hamon 2009: 79).

The rocks arriving at Dambach-la-Ville travelled about 15 kilometres as the crow flies, a distance that can still be regarded as local procurement (Figure 3). The slight wear of the tools is probably linked to the proximity of source, as it was simpler to make a new tool than rework an old one (Hamon 2009: 90). Secondary fashioning of worn tools is in fact only evident in 15 cases. 


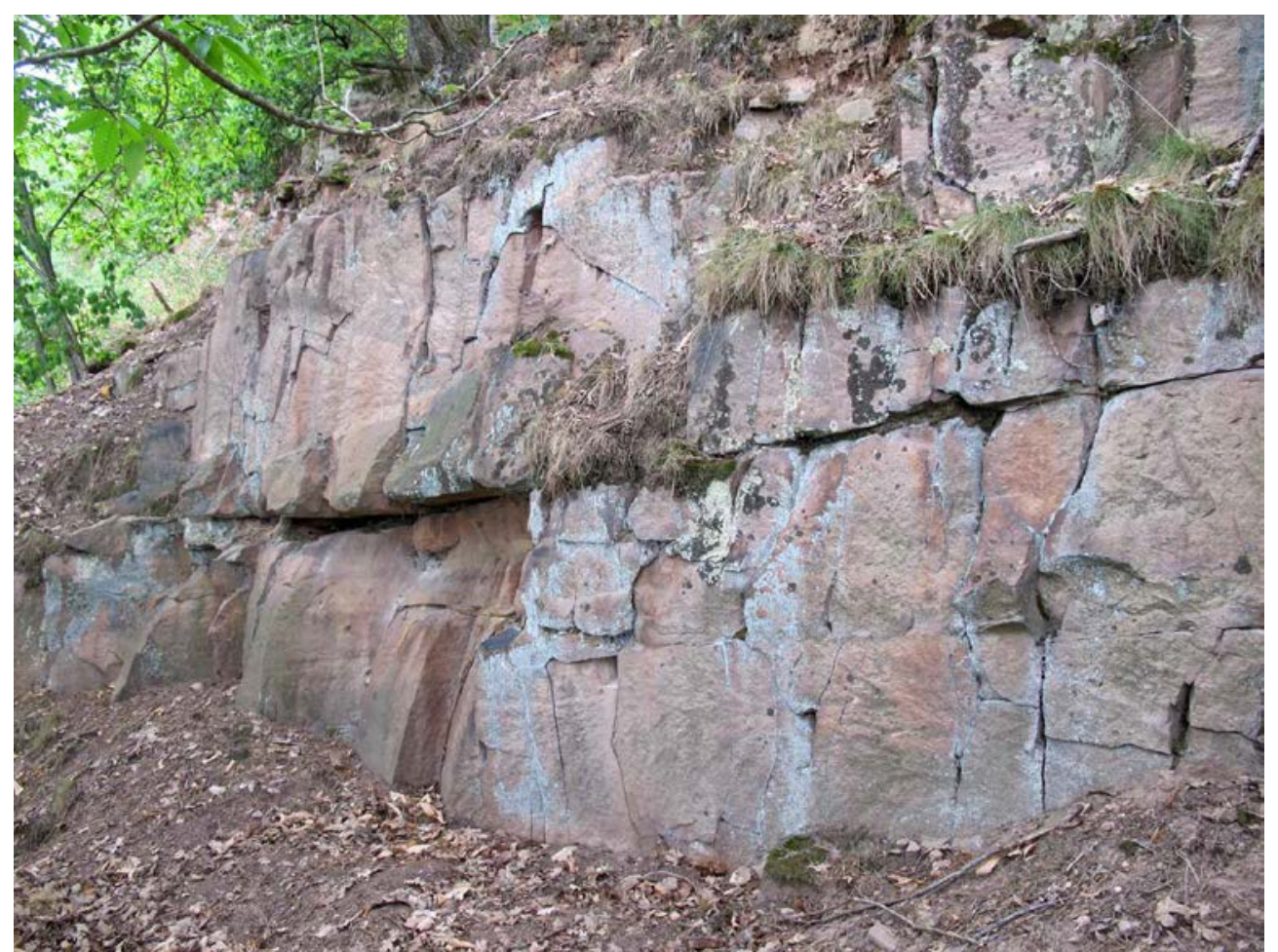

Figure 2. Planar fractured sandstone quarry face indicative of angular block or slab extraction (photo: Fl. Jodry, Inrap).

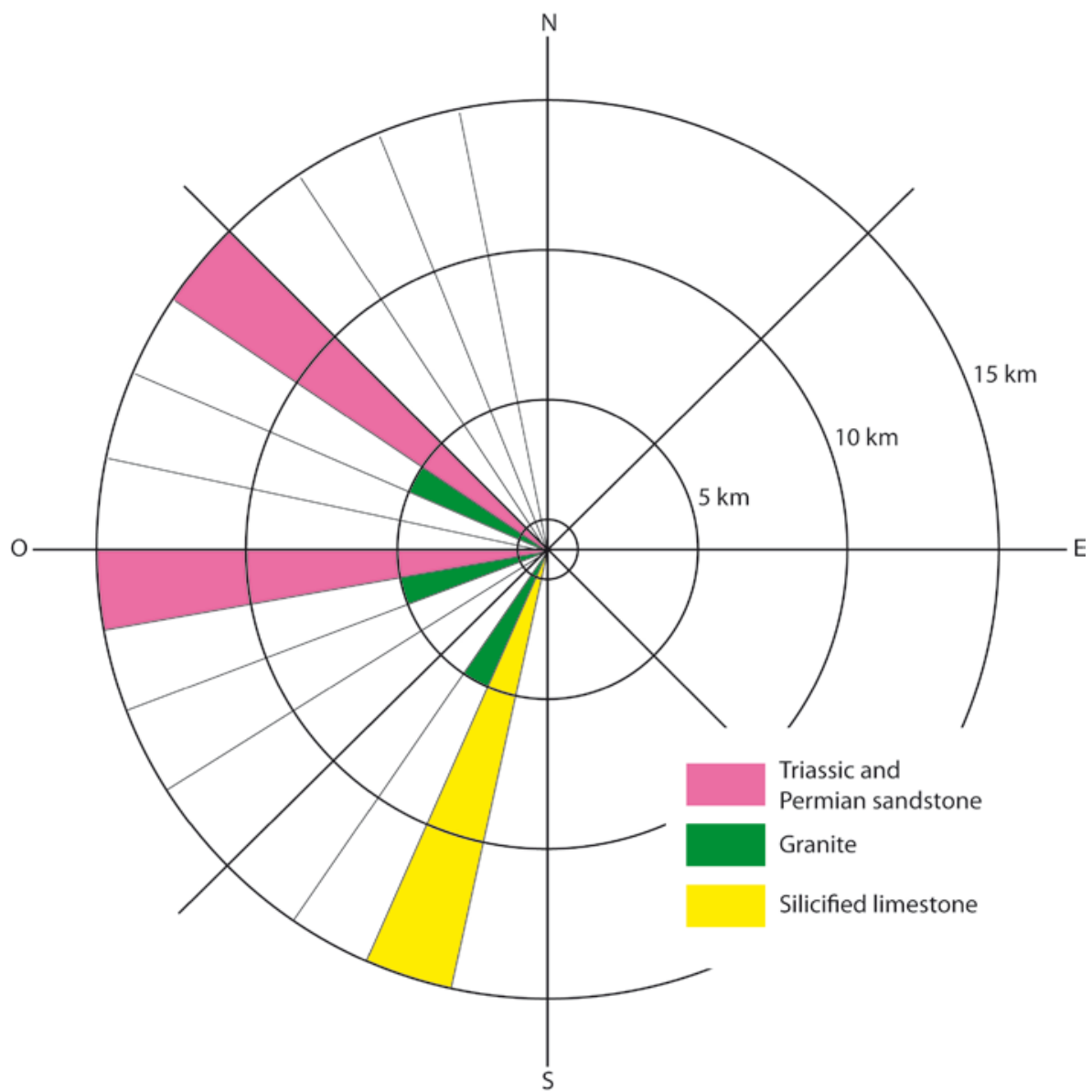

Figure 3. Sketch of the different potential rock outcrops directions in the surroundings of Dambach-la-Ville (CAD Jodry, Inrap). 


\subsection{Querns}

The quern assemblage comprises 179 fragments of 142 lower stones (saddle querns) and 342 fragments of 318 upper stones (rubbers). The analysis was limited to four whole and 139 fragmented pieces. These querns were fashioned in almost equal proportions from the three most frequently imported rocks: arkosic sandstones (37\%), microconglomerates (31\%) and coarse quartzitic sandstones (31\%).

Most of the backs and flanks of the querns were either pecked (85 cases; 72\%), left rough (20 cases; $17 \%$ ) or roughly flaked (8 cases; 7\%). Moreover, $95 \%$ of the cases of pecking were applied to arkosic sandstones and microconglomerates, whereas this technique is rarely observed (5\%) among coarse quartzitic sandstones.

\subsection{Upper stones}

The 318 upper stones can be broken down into 16 whole and 297 fragmented examples. The type of rock chosen to fashion the upper stones of the querns is identical to that of lower stones. Arkosic sandstones (153 items) dominate the assemblage (48\%) followed by 94 coarse quartzitic sandstones (29.5\%), slightly ahead of 62 microconglomerates (19\%). To this, five fine sandstones and three granites can be added. The backs and flanks of the upper stones of these querns is identical to that of the lower stones. It is noteworthy that of the 318 upper stones, 20 correspond with the "bar" type while nine are of the "overlapping" type (Figure 4).

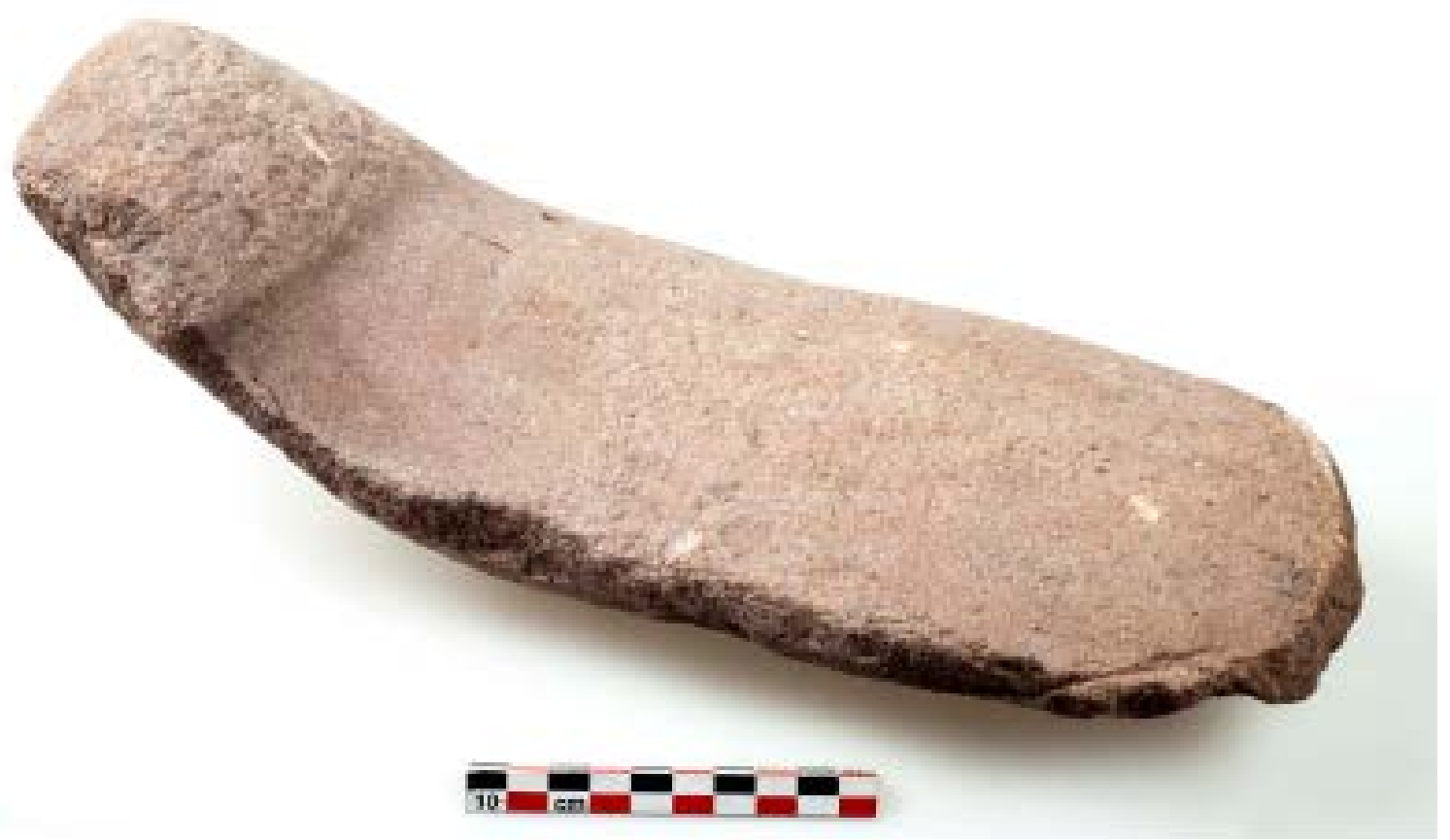

Figure 4. Grinding surface of an overlapping upper stone quern RLT-331-6 (photo: Fr. Schneikert, AA).

A morphological characteristic of "overlapping” upper stones is a concave or curved grinding surface (Hamon et al. 2017) flanked by lateral convex surfaces corresponding to where the stone's active surface exceeds the width of the lower stone. The lateral "outgrowth" can subsequently be removed by pecking. Overlapping querns are known at other Alsatian sites and elsewhere in the context of the Linear Band Keramik (Rubané) Culture. This type is also recorded at Middle Neolithic sites in the eastern half of France (Hamon et al. 2017).

A characteristic of overlapping upper stones is linked to the position of the hands. The analysis of overlapping upper stones reveals that the hands grip the stone at each end (Hamon 
et al. 2017). Yet, there are also indications among the Dambach-la-Ville assemblage that point to the fashioning of either a prehensile "bar" (Figure 5) or lateral grips (Figure 6).

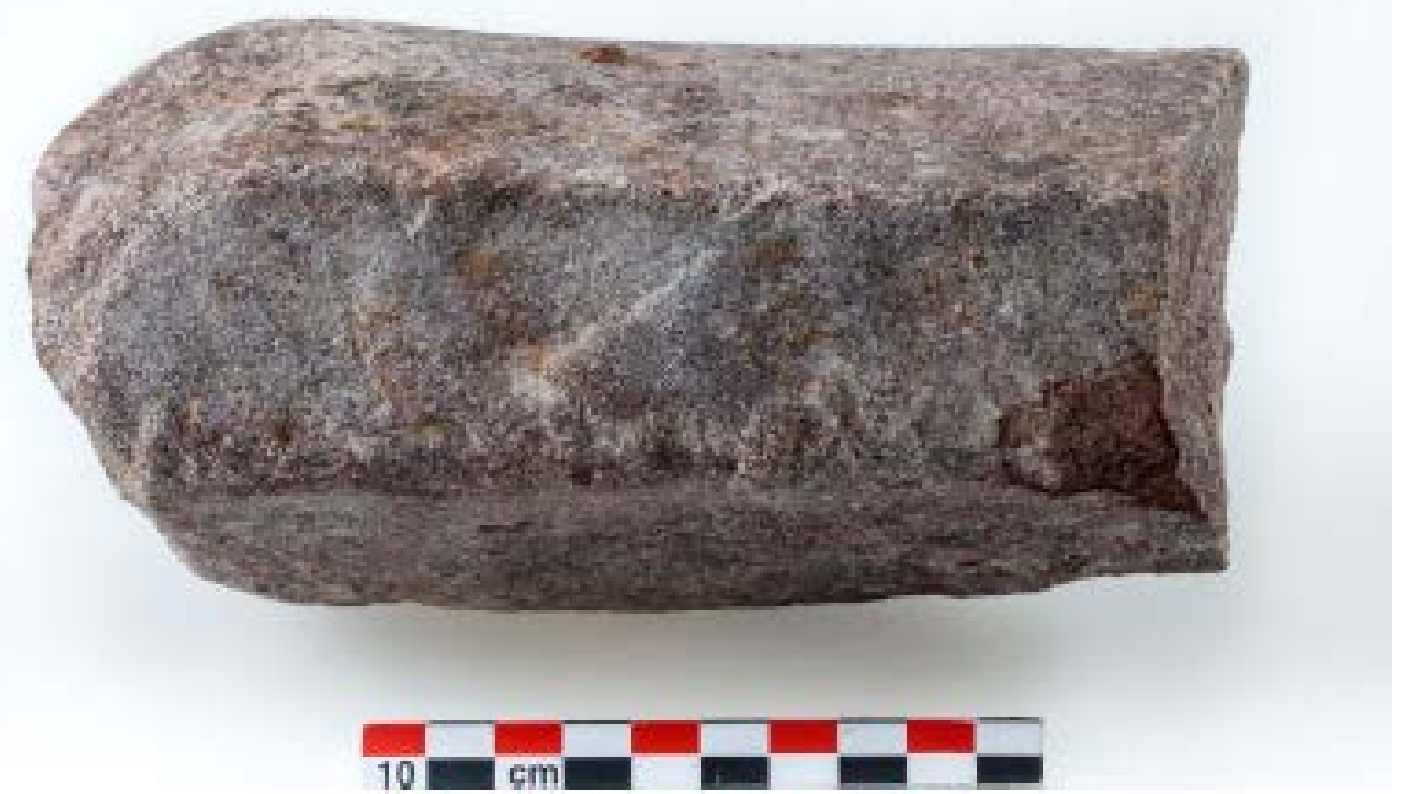

Figure 5. Back of a quern upper stone RLT 2-1104 with a prehensile "bar" serving to grip the tool (photo: Fr. Schneikert, AA).

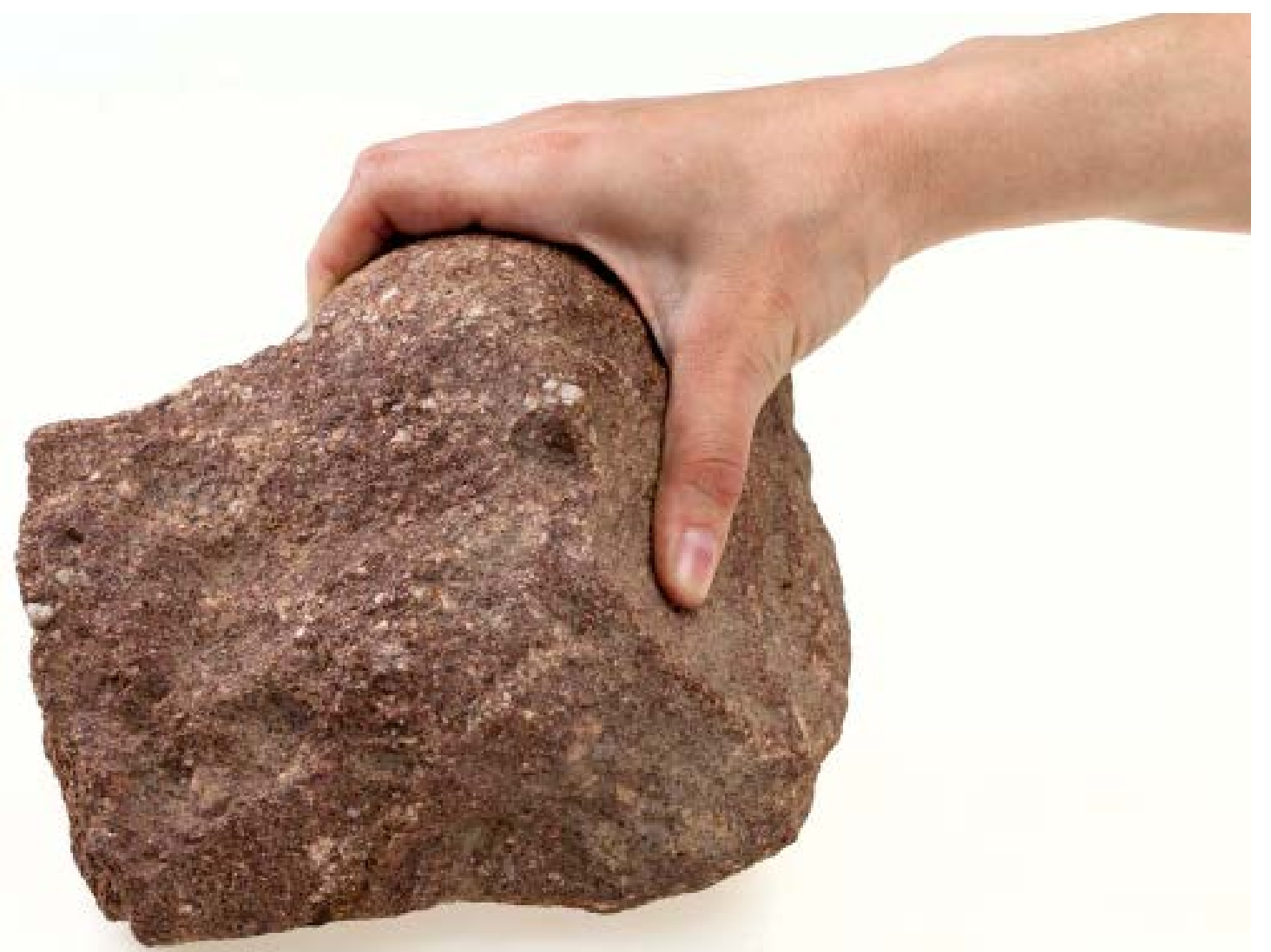

Figure 6. View of quern stone RLT 1-9 with a lateral grips serving to grip the tool (photo: Fr. Schneikert, AA). 


\section{Hammerstones}

The assemblage contains 171 hammerstones of which 92 are whole. Although most (127 items) were brought to light in the backfill of dug-out Middle Neolithic structures, 44 were collected out of context during the initial stripping of the site by backhoe. From the petrographic perspective, the assemblage comprises 22 different rock types (sedimentary, metamorphic, plutonic and volcanic rocks: Figure 7).

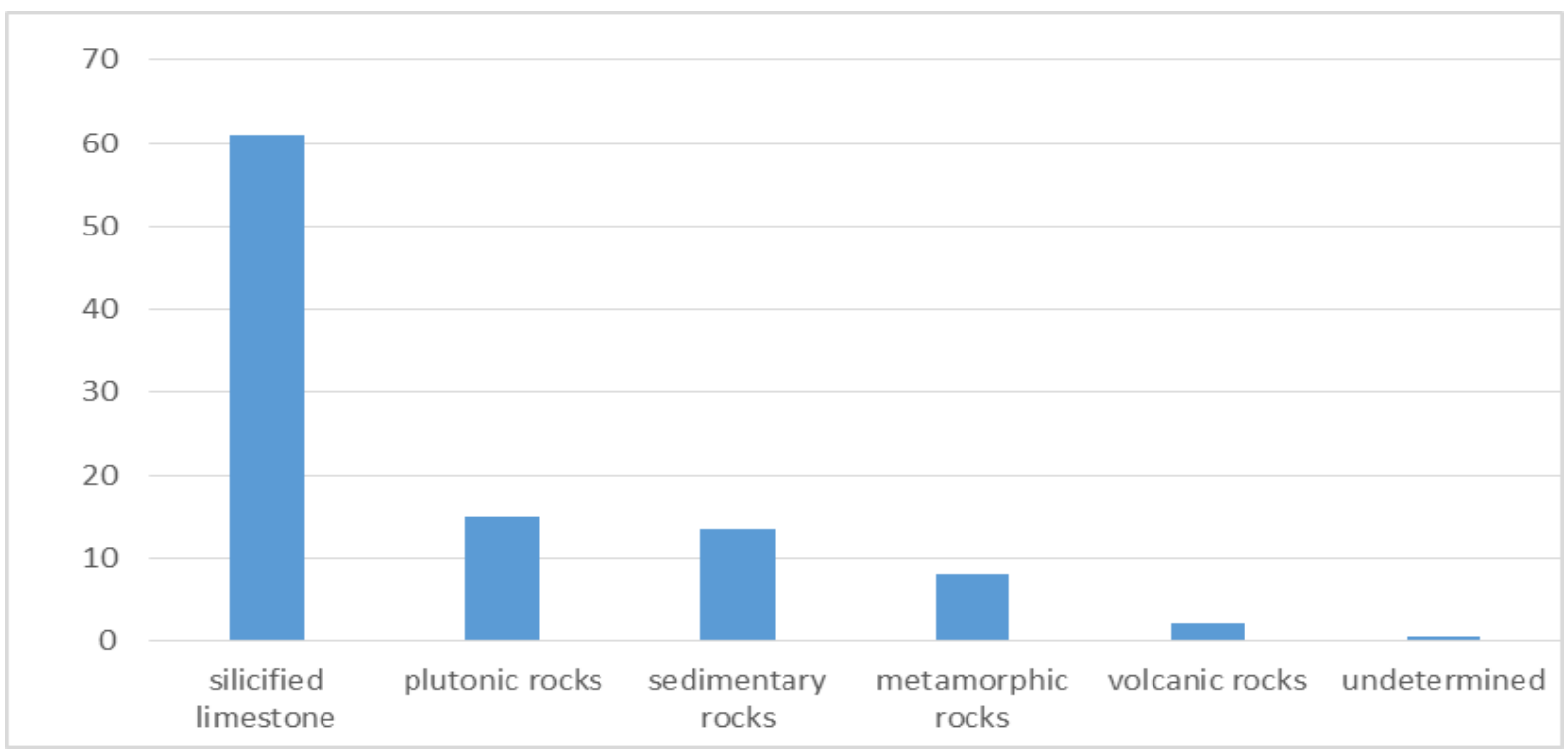

Figure 7. Proportional frequency of the hammerstone rock types at Dambach-la-Ville.

The hammerstones are for the most part sedimentary stones (126 items) with a high proportion of silicified limestones (59.9\%). The origin of this particular rock can be identified based on least two stages of its formation: an initial sedimentary phase typical of all limestones preceding a complex tectonic and metasomatic phase leading to a total or partial silicification. This specific type of formation process is rare in the region. However, the structures and the colours of the samples unambiguously link these stones to the Entrochal limestone formation (calcaires à entroques). Although this formation is practically ubiquitous in the fracture field along the Vosges border, there is only one outcrop in Alsace located in the surroundings of the Castle of Reichenberg, adjacent to the Bergheim-Schluesselstein area to the north of the Colmar-Ribeauvillé fracture (Figure 8).

Silicified rocks serving for hammerstones throughout this zone $15 \mathrm{~km}$ from Dambach-laVille therefore could have been extracted directly from outcrops in the silification zone in Figure 8-b (outcrop photo in Figure 9). It is also noteworthy that loose rocks that could have potentially served to easily fashion hammerstones (e.g., quartzites in Rhine alluvial deposits) are available in the immediate vicinity of the settlement of Dambach-la-Ville, but are rare among the assemblage.

The morphology of hammerstones ranges from globular to oval indicating they were fashioned for the most part from rounded pebbles or small blocks. In more than a quarter of the cases, the tools originally were irregular pebbles either roughly spherical or ovoid while possessing concave, flat or convex facets (Figure 10).

The dimensions and weight of the whole hammerstones range between $5.5 \times 5.2 \times 5.5 \mathrm{~cm}$ (200 g) for the smallest, and $21 \times 14 \times 10.5 \mathrm{~cm}(4,820 \mathrm{~kg})$ for the largest. Most are less than $10 \mathrm{~cm}$ long (72 items) and only five weigh more than a kilo. Use-wear traces cover their surfaces, edges, facets or form a band along their periphery. The position of the traces is obviously linked to the general morphology of the original pebble and depends on the surface 
features described above. The density and repetition of impacts very often led to a change in the shape of the stone with flattened or faceted faces or surfaces and edges. In some cases, the force of the impact resulted in a flaking scar or even breakage.
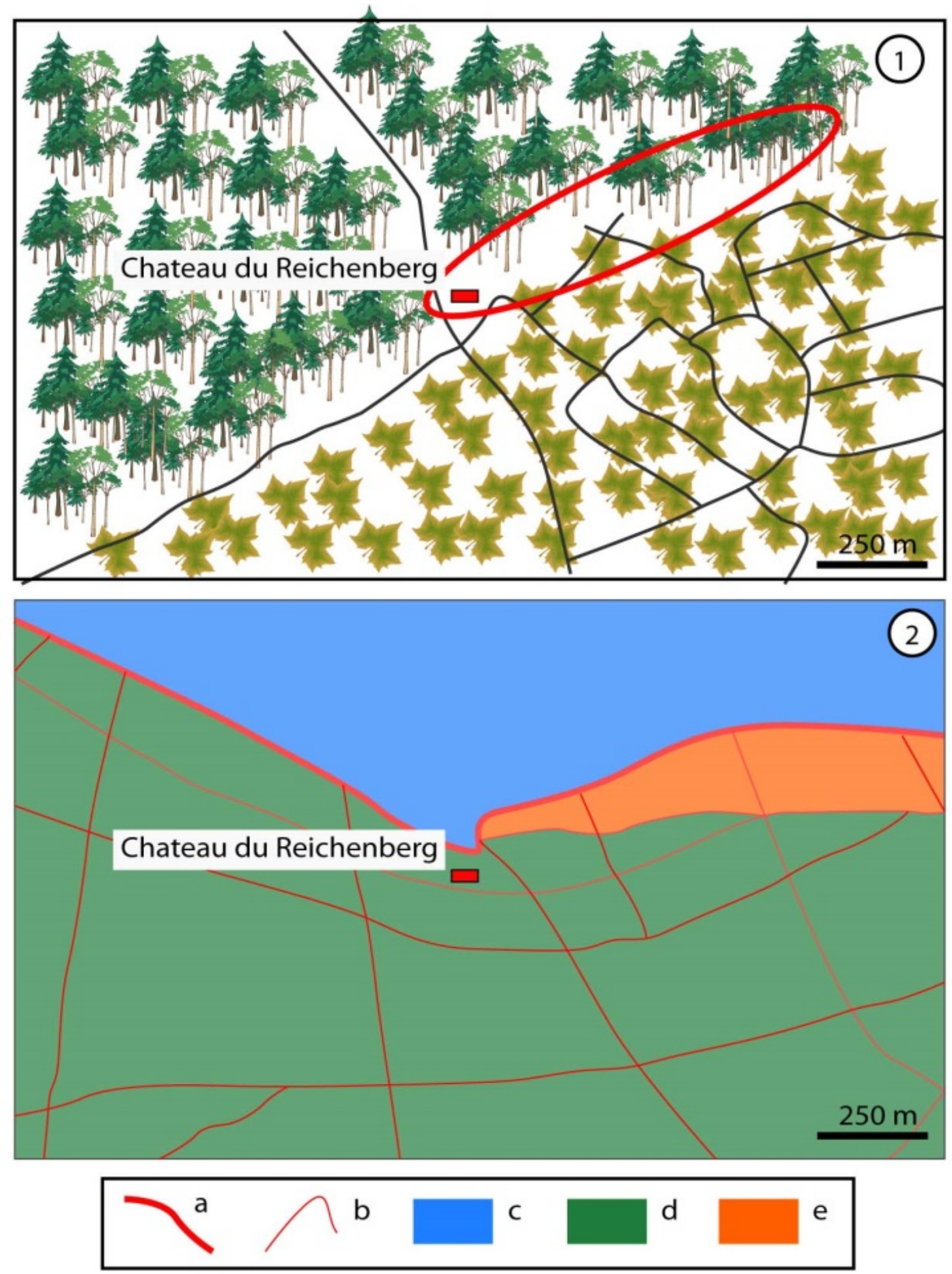

Figure 8. Sketch of the silicified limestone outcrops indicated with a red ellipse (view 1. The schema (view 2) indicates the a) Vosges fault line, b) faults in the fracture field, c) the Palaeozoic massif consisting mainly of granites and a Carboniferous sedimentary cover, d) the fracture field dominated by limestones, marls and Mesozoic sandstones, e: the principal silicification zone surrounding the limestones of the Upper Muschelkalk (Indian beads Limestone facies) (CAD Fl. Jodry from Ph. Duringer, IPG-EOST). 


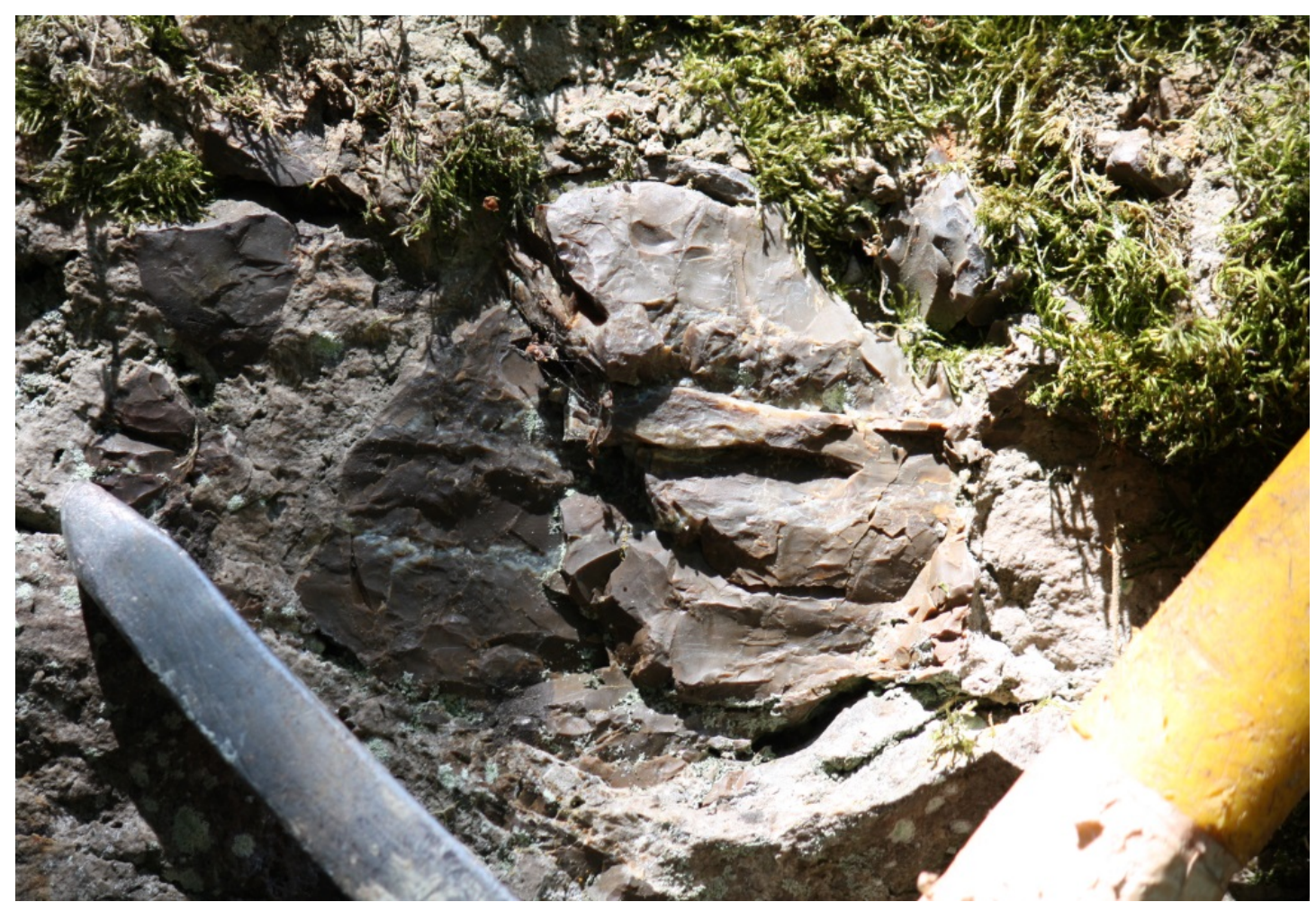

Figure 9. Example of a silicified limestone outcrop at Bergheim (Haut-Rhin) (Photo: M. Delloul, AA).

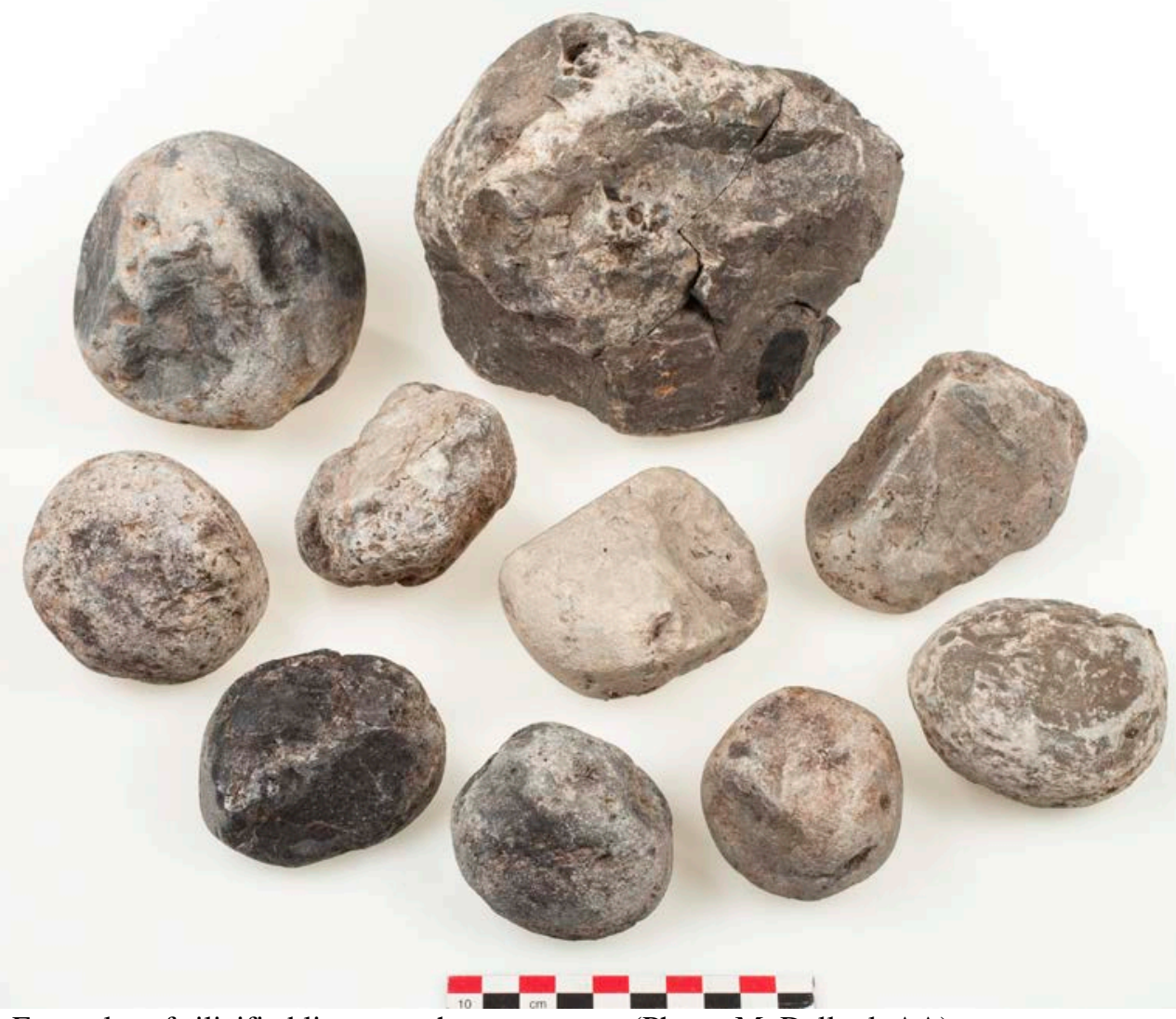

Figure 10. Examples of silicified limestone hammerstones (Photo: M. Delloul, AA). 


\section{The raw materials for the grinding tools}

The rocks selected for the manufacture of grinding tools are for the most part sedimentary: Permian arkosic sandstone, (micro) conglomerates, and coarse Triassic sandstones (Figure 11).

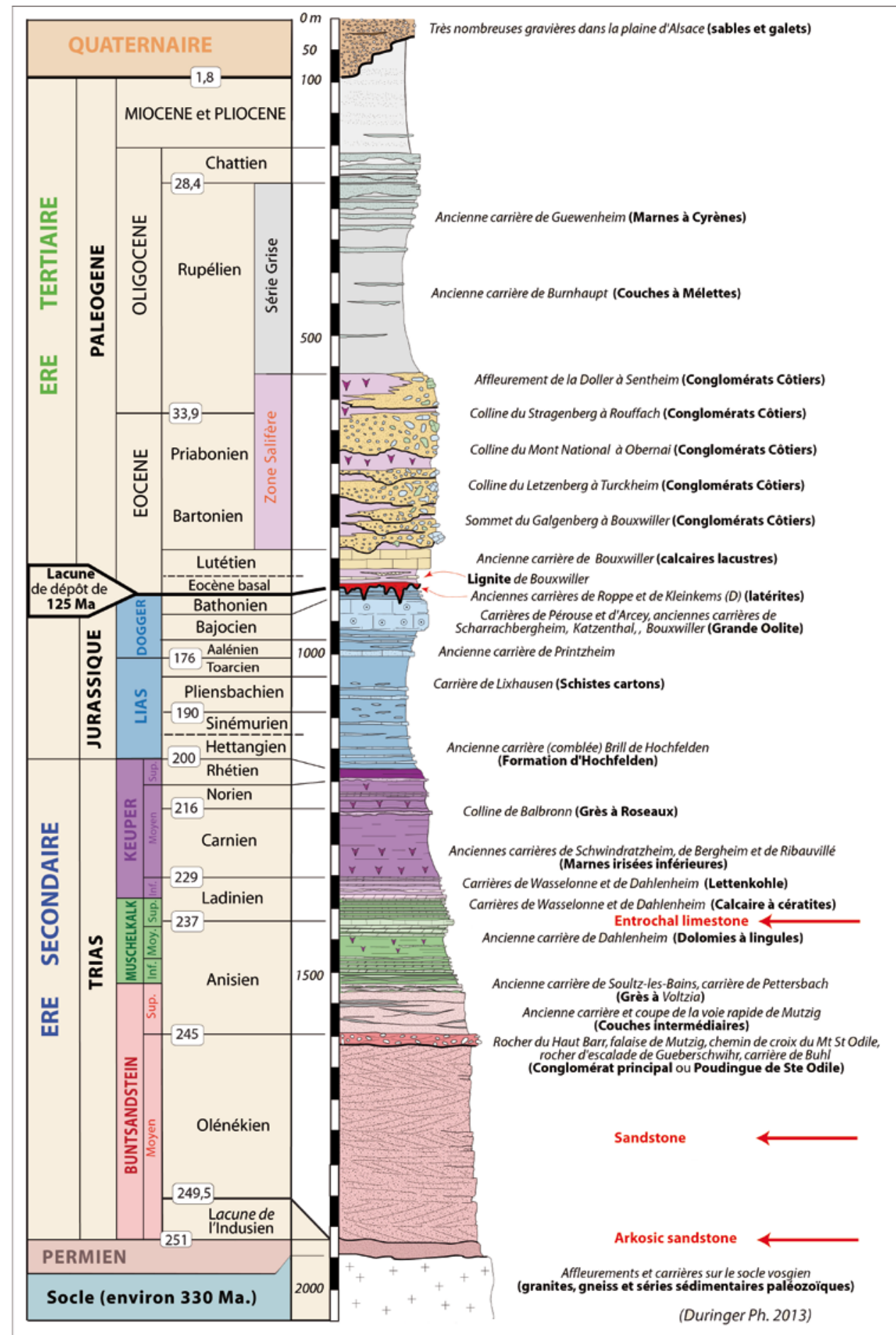

Figure 11. General stratigraphic sequence of the "Alsace” region. The thickness of the layers is to scale except for the highly variable Permian layers and deposits at the base of the sequence that group a number of rock types (plutonic, volcanic, subvolcanic, metamorphic and sedimentary) (Ph. Duringer, IPG-EOST). The rocks used for the tools written in red. 


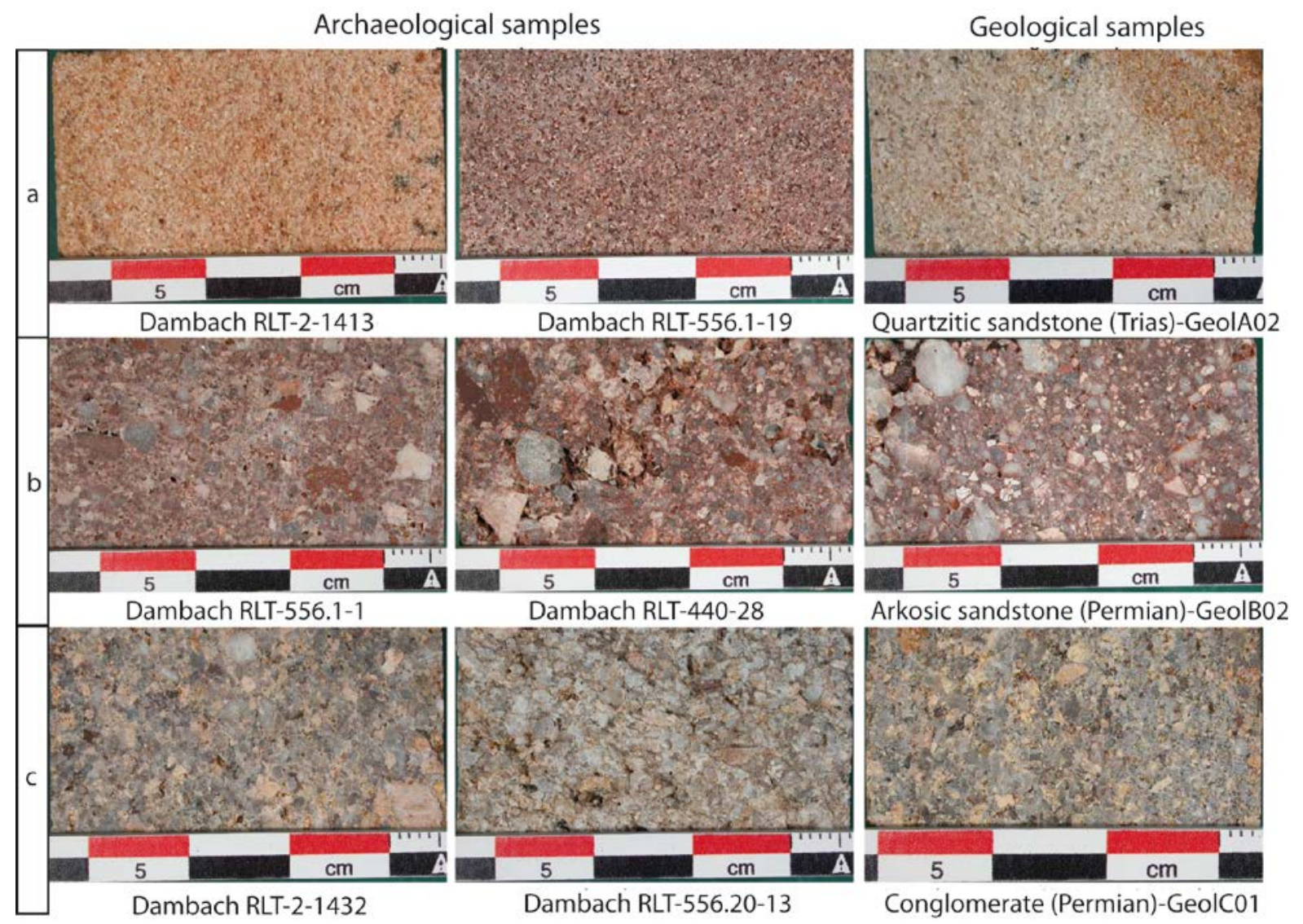

Figure 12. Macrophotograph of samples of: a) Vosges quartzitic sandstone, b) arkose and c) conglomerate (Photo: X. Drothiere \& G. Fronteau).

The samplings of the different materials of the assemblage point to three main types of sandstone and conglomerate facies. Moreover, all the preliminary macroscopical determinations carried out during the study were additionally validated by microfacies petrographical analyses. Furthermore, the archaeological samples clearly correlate with the geological samples collected at the outcrops, which is confirmed by both the macroscopic and petrographic studies. The samples within each facies reveal slight intra-group variability. However, that does not question the division into three main or major rock types applied to the study.

The quartzitic Vosges sandstone can be clearly distinguished from the other two rocks by its fine granulometry and compact cementation (Figure 12a). It is an unusual rock within the stratigraphic sequence of the Vosges Triassic layers, with properties which are very close to those of the Cenozoic quartzitic sandstone facies that served as a source of tools in the north of the France (Hamon \& Fronteau 2018) and the south of Belgium (Reniere et al. 2016: 415416).

The arkose facies (Figure 12b) among the Dambach tools is coarse grained and may be confused with microconglomerates. Yet as noted above, its cementation is siliceous which however does not increase its hardness or durability. This characteristic therefore renders it more suitable for chipping than the conglomerates (Figure 12c) as its siliceous cementation increases its cohesion without hardening the rock.

\section{Conclusion}

Pebbles with facetted surfaces that assured a good grip were favoured for hammerstone production at the site of Dambach-la-Ville. The choice of the raw materials demonstrates a 
deliberate collection and excludes the notion that the material was gathered at random. Silicified limestone pebbles were used extensively, as evident from the many examples of hamerstones bearing traces of use-wear. Silicified limestones are chemically very close to flint in the broad sense, but they do not bear the vitreous-like characteristic of flint and cannot be knapped for blades or chips. Hence, the use of silicified limestone as hammerstones is most likely explained by its hardness.

The rocks serving for grinding tools, as well as for hammerstones, appear to have been chosen and fashioned dependent on specific material properties. Yet, the material characteristics of the Permian rocks, together with the fact that they could have been easily procured obviously did not motivate their systematic exploitation as they are rarely identified among Neolithic, Protohistoric or Roman assemblages (Jodry 2012; 2019). The proportion of arkosic sandstone tools is exceptional at Dambach-la-Ville. Therefore, it is likely that its choice can be connected to a specific (but not exclusive) use such as dehusking grain (Croutsch et al. 2015; Hamon et al. 2011: 46), a hypothesis still to be confirmed.

It is difficult to compare the Dambach-la-Ville assemblage with other regional Middle Neolithic tools groups as it comprises such a great number of tools and includes many typological varieties: narrow lower stone querns; short, overlapping and bar-shaped upper stone querns, sometimes with lateral grips, etc. Therefore, in terms of lithic procurement, variety of rock types and typo-technology, Dambach-la-Ville is an exceptional reference for both grinding stones and hammerstones.

\section{References}

Croutsch, C., Tegel, W., Rousselet, O. 2015, Dambach-la-Ville/Plateforme départementale d'Activités d'Alsace Centrale (Bas-Rhin, Alsace): Un village de la fin du 5e millénaire. Analyses dendrochronologiques et premières données sur l'économie et l'environnent à travers la carpologie. In: Occupations et exploitations néolithiques : et si l'on parlait des plateaux ? 31e Colloque Internéo Actes du colloque de, Châlons-en-Champagne octobre 2013. Reims (Laurelut, L. \& Vanmoerkerke, J., Eds), Société archéologique Champenoise, Bulletin de la Société champenoise, 107(4): 35-44. (in French) ("Dambach-la-Ville/Departmental Platform of Activities of Central Alsace (Bas-Rhin, Alsace): A village at the end of the $5^{\text {th }}$ millennium")

Croutsch, C., Affolter J., Duringer Ph., Fronteau, G., Jodry Fl., Klee J., Kucharski M., Lefranc Ph., Leprovost C., Locatelli, Ch., Nocus N., Pousset D. Rault E., Rousselet O., Putelat O., Tegel W. \& Wuscher, P. 2016, Dambach-la-Ville/Plateforme départementale d'Activités d'Alsace Centrale (Bas-Rhin, Alsace): Un habitat néolithique de la deuxième moitié du Ve millénaire av. J.-C. et indices d'une occupation de l'âge du Bronze ancien. 3 vol., Rapport de fouille préventive no. 5757, PAIR 2016, 454p. (in French) ("Dambach-la-Ville/Departmental Platform of Activities of Central Alsace (Bas-Rhin, Alsace): A Neolithic settlement from the second half of the $5^{\text {th }}$ millennium BCE and indications of the occupation in the early Bronze Age")

Hamon, C. 2009, L’outillage en grès. In: Le Néolithique ancien dans la Basse Vallée de la Marne: un site VSG, producteur de lames en silex tertiaire à Ocquerre «La Recluche» (Seine-et-Marne), (Praud, Y., Ed), Travaux 9 de la Société Préhistorique Française, Paris, p. 77-97. (in French) ("Sandstone tools”) 
Hamon, C., Farget. V., Jaccottey, L., Milleville, A., Monchablon, C. 2011, Propositions de normes de dessin et d'une grille d'analyse pour l'étude des meules va-et-vient du Néolithique à l'âge du Fer. In: Évolution typologique et technique des meules du Néolithique à l'an mille: actes des IIIe rencontres archéologiques de l'Archéosite gaulois (Buchsenschutz, O., Jaccottey, L., Jodry, F. \& Blanchard, J.-L., Eds.). Supplément à la Revue Aquitania; 23: 39-50 (in French) ("Suggestions of design norms and an analysis raster for the study of hopper-rubber mills from the Neolithic to the Iron Age period").

Hamon, C., Brisotto V., Jaccottey L., Monchablon C., Cousseran-Néré S., Donnart K., Duda T., Gisclon J.-L. \& Milleville A. 2017, Les molettes débordantes au Néolithique: définition et premier état des lieux. In: Les meules du Néolithique à l'époque médiévale: technique, culture, diffusion, Actes du 2ème colloque du Groupe Meule, Reims, du 15 au 17 mai 2014 (Buchsenschutz, O., Lepareux-Couturier, S. \& Fronreau, G., Eds.) 43ème supplément à la Revue Archéologique de l’Est, S.A.E., Dijon, p. 301-316 (in French) ("Overlapping mills from the Neolithic period: Definition and a first inventory”)

Hamon, C. \& Fronteau, G. 2018, Linearbandkeramik sandstone supply strategies in northwestern Europe: the example of macrolithic tool production in the Aisne Valley, France (late 6th millennium BCE). Journal of Archaeological Science: Reports, 19, 301-311. doi:10.1016/j.jasrep.2018.02.049

Jodry, F. 2012, Le matériel de mouture en Alsace du Néolithique à La Tène finale. Le potentiel géologique des Vosges et les » importations » sur les sites d'habitat. In: Roches et Sociétés, entre massifs cristallins et bassins sédimentaires. Rennes: Presses Universitaires de Rennes, Rennes, p.251-261. (in French) ("The milling equipment in Alsace from the Neolithic to the late La Tène period. The geological potential of the Vosges and the "imports" on settlement sites")

Jodry, F. 2019, Les outils macrolithiques: 5000 ans d'exploitation dans les Vosges. In: Des ressources et des hommes en montagne. Editions du Comité des travaux historiques et scientifiques, Pau, Paris, p.1-16. (in French) ("Macrolithic tools: 5,000 years of sampling in the Vosges mountains"). doi:10.4000/books.cths.5637.

Reniere, S., De Clerq, W., Dreesen, R., Gomaere, E., Fronreau, G., Gluhak, T.M., Hartoch, E. \& Picavet. P. 2016, Querns and mills during Roman times at the northern frontier of the Roman Empire (Belgium, Northern France, Southern Netherlands, Western Germany): Unraveling geological and geographical provenances, a multidisciplinary research project. Journal of Lithic Studies, 2016, 3(3): 403-428. doi:10.2218/jls.v3i3.1640 